\title{
Literature Review of the Classifications of "Needs" in Needs Analysis Theory
}

\author{
LI Juan \\ School of Foreign Language Studies, Shandong Jiaotong University, Jinan, China
}

Received: 10-05- 2013

doi:10.7575/aiac.ijels.v.2n.3p.12
Accepted: $12-06-2013$

URL: http://dx.doi.org/10.7575/aiac.ijels.v.2n.3p.12
Published: $30-07-2014$

This research is supported by the Research Base of Humanities and Social Sciences of Shandong ProvinceInternational Business Study Center and a grant from Research Program of Education and Teaching of Shandong Jiaotong University: Curriculum Design for Business English Students Based on Needs Analysis Theory: A Case Study of Shandong Jiaotong University with the grant No. JY201211.

\begin{abstract}
Needs analysis makes it possible that the language course can cater to the needs of learners from different countries, different language levels and different targets. A well-established needs analysis may provide references for the policy making, curriculum design of foreign language teaching. This paper reviews the point of view of some researchers and tries to tease out the "needs" and its classifications in needs analysis theory with an aim to giving some implications to the study in the relevant field of study.
\end{abstract}

Key Words: needs, needs analysis, classifications

\section{Introduction}

Needs analysis is an essential step in foreign language curriculum design. Nunan (1988) argues that needs analysis is a starting point of the design of a syllabus or a curriculum. It is of crucial importance to design a focused course which caters to the needs of different shareholders, including learners, language teaching institutions, and employers. A professional and precise needs analysis ensures the efficiency of language teaching and thus facilitates reaching the previously set goals. The data obtained in a needs analysis process can also be used as benchmarks to review and reevaluate the existing curriculum. After two or three decades of development, the connotation of needs and needs analysis is gradually broadened. This paper will review the definition of needs and the classification of the needs in needs analysis theory according to different scholars from different perspectives.

\section{Needs Analysis}

Needs analysis, as a term related to language teaching, first appeared in the 1920s (White, 1988; West, 1997). However, it became popular in the decade of the $70 \mathrm{~s}$ and early $80 \mathrm{~s}$ by means of some major publications, which were associated to ESP teaching such as those by Richterich and Chancerel (1980) or Munby (1978). With the focus transferring from learners' language needs to the learning needs, needs analysis was applied in the English for General Purposes (EGP), and has been an indispensable step in the course design of foreign language teaching.

Up to now, the most frequently quoted definition for needs analysis is from Brown (1995). According to him, needs analysis is the activities of information gathering process. The information will be considered by the course designers to develop a curriculum that caters to the needs of a definite group of learners. Needs analysis is considered to be an integral and indispensable part of systematic curriculum design.

According to Richard, Platt, and Weber (as cited in Brown, 2001, p. 35), needs analysis is defined as a process that determines the needs of a learner or a group of learners, who require a language and sequence the needs on the basis of priorities. In the process, both subjective and objective information are employed in needs analysis, such as data from observation, interviews, tests, and questionnaires. Notice that the needs described in this definition are those of the learners involved and also notice that the learner's language requirements are to be described and prioritized on the basis of both subjective and objective information. According to their definition, needs analysis is the process of establishing the "what and how of a course" (Dudley-Evans and St John, 1998).

McCormick, Stufflebeam, Nelsonand and Brinkerhoff (as cited in Brown, 2001, p.16) have a broader definition for needs analysis. According to them, needs analysis is the process that determines the things necessary or useful for the accomplishment of a "defensible purpose". In their definition, "defensible purpose" is particularly emphasized.

Pratt (1980) states that, needs analysis refers to "an array of procedures" that can identify, validate, and prioritize needs. The key phrases that differentiate this definition from the others are "an array of procedures" and "to validate needs". "An array of procedures" indicates that during the process of needs analysis, a variety of information-gathering tools 
can be employed; while "to validate needs" indicates that needs are not absolute and once identified, they should be examined continually for the validity to ensure that they are the real needs for the learners involved.

Needs analysis can be used to check the previous assumed educational needs by the educators. It makes sure that the specific curriculum is responsive to the needs of the learners. In this sense, needs analysis greatly facilitates the educational organizations and the educators to develop learner centered teaching materials, selecting the appropriate teaching methods, and making fair assessment. The use of needs analysis makes the language teaching more targetoriented and effective. Needs analysis can be done at any time of the language program. If it is carried out at the beginning of the course, it may provide the instructor with the information about what the learner brings to the course; if it is done during the course, the instructor may have a general overview of what has been accomplished through this course and what the learner wants and needs to know in the future. Learned that the educators want to find the specific needs and interests, learners will be further motivated to learn.

\section{3. "Needs" in Needs Analysis}

Various authors have discussed the different meanings of needs. According to Widdowson (1981), needs refers to the present or future requirement of learners, and what they expect to learn when they finish the language course.

Likely, Mountford (1981) holds the opinion that needs refers to what is perceived by the teaching organization or the society as necessary to learn from a language program or instruction. These two definitions, which take needs as objectives of the learners' study or working requirement, are both goal-oriented. In contrast, Richterich (1980) holds the opinion that the identification of language needs should include the information of the learners who will attend a language course and how they expect to make use of it when they finish the course. Brindley (1989) states that needs may equal to learners" "wants" or "desires" which refers to what the students themselves would like to learn in addition to their program requirements. Berwick (1989) defines "needs" as "the gap between the current situation and the anticipated future state" (p. 52). These researchers are process-oriented and they focus more on what the learner needs during the language acquiring course or what the students would like to gain from the language course. To summarize, goal-oriented needs derive from the target situation and process-oriented needs derive from the learning situation. (Dudley-Evans \& St. John, 1998)

Sometimes needs can be interpreted as inadequacies to be filled, like what the learners currently can not do or do not know about the language (Robinson, 1991). Sometimes, when deciding the goal or the content of a course, it is applicable to compare the views of learners with the teaching authorities. When doing this, "conflict" may also inevitably occur between learners and teachers when designing the learning activities, formatting strategies and selecting materials and learning content (Brindley, 1984). No matter what needs are considered to be, objectives should be based on them.

\section{The Classifications of "Needs"}

With regard to the classifications of needs, scholars hold different views as well. The following is a review of the major classifications of needs according to different researchers.

\subsection{Perceived Needs and Felt Needs}

Berwick (1989) distinguished perceived needs from felt needs. He defined the perceived needs as objectives set according to others' learning experiences, and the felt needs as the learner's own needs. In his view, perceived needs were the thoughts of experts about the educational gaps in other peoples' experiences. Perceived needs were often considered as normative, real, and objective, in the sense that they reflected teachers' or educational settings' outside perceptions of learners' language needs. On the other hand, felt needs were those needs that the learners thought they needed. Felt needs were related to the feelings, thoughts, and assumptions of the learners. They can be defined as "wants" and "desires" of the learners.

\subsection{Object Needs and Subjective Needs}

Both Brindley (1989) and Robinson (1991) offered the concepts of objective needs and subjective needs, which were another classifications of needs types. Objective needs are the needs that are inferred from the "factual information" of learners, which include their language proficiency when attending the courses, the perceived language difficulties and their demand of language in real communication situations (Brindley, 1989).

Objective needs are, therefore, those needs that are identified on the basis of clear cut, observable data gathered about the situation, the learner, the language that learners must acquire, and learners' present proficiency and skill level (Brown, 1995). Objective needs can be diagnosed by teachers on the basis of the analysis of personal data about learners' biographical data, such as age, gender, nationality, marital status, educational background, pre-learned language courses, current language proficiency, patterns of language, difficulties in foreign language learning, current or future profession. This information should be embedded into the process of assessing objective needs.

In contrast, subjective needs are the language learning cognition and emotional needs of learners. It refers to the needs that are inferred from the "affective and cognitive factors" of the learners. These factors include the learners' personality, self-confidence, personal cognitive styles, expectations: and self-esteem during the learning process (Brindley, 1989).

According to Graves (2000), to assess the subjective needs, some information about the learners should be collected. For example, the learners' attitudes towards learning, the targeted culture, the language, their expectation for 
themselves and for the language course, and their "underlying purposes". Sometimes subject needs cannot be diagnosed easily, in many cases, even cannot be stated clearly by learners themselves.

\subsection{Target Needs and Learning Needs}

Hutchinson and Waters'(1987) two concepts of needs: "target needs" and "learning needs", are preferred and frequently cited by Chinese researchers. "Target needs" refers to the learner's "necessities", "lacks" and "wants" for functioning effectively in the target situation; while "learning needs" concerns about the learner's motivation and attitudes, interests, personal reasons for learning, learning styles, resources and time available.

\subsubsection{Target Needs}

To illustrate the "target needs" more explicitly, it is more useful to look at the target situation in terms of "necessities", "lacks" and "wants".

Hutchinson and Waters (1987) are the authors who advocate the target needs in their work English for Specific Purposes. According to them, "necessities" is determined by the requirement of the target situation, in which the learner must master the language for the purposes of effective function. For business learners, for example, they should master the reading skills in instruction manual, professional books and journal, biding and quoting techniques; the writing skills in emails, contract, memos, and reports; The oral skills such as telephoning, business presentation, negotiation and banquet and the translation skills of business letters and documents. The linguistic features of business texts, such as the discourse, structural, factional, and lexical characteristics, are also necessary for the business learners to master in the identified situations. To gather the information stated above, observing the learners' target situation and the analysis of the constituent are practical and effective.

To merely specify the necessities alone is not enough, since the needs of particular learners are emphasized in language teaching. In that case, what the learner already knows should also be identified, then "lacks" of learners can be concluded by comparing the necessities with what the learner already knows. Then, the language teaching institution can decide whether or not (or to what extent) the instruction should be given to learners. That is to say, learners' lack comes from comparing the "target proficiency" and the "existing proficiency" (Hutchinson and Waters, 1987).

Hutchinson and Waters' (1987) definition of target needs emphasizes allowing students to express their own expectations towards their target situation requirements. The concept of "wants" shares the same cognition with objective needs and subjective needs. "Target needs" is considered from the objective perspective without considering the role of the learners. However, the fact is that the learners do have the idea of what their needs are. Since subjective needs are related to the students' feelings and expectations about their language needs, they reflect the "wants" defined by Hutchinson and Waters' (1987) and are the subjective needs of the learner. Therefore, teachers probably perceive the objective needs and learners may perceive their subjective needs. A lot of cases in the development of business English have shown that there is no necessary relationship between the necessities perceived by the designers and what the learners want or feel what they need. Sometimes, the learner's perception of needs may even be in conflict with that of course designers, so it is necessary for the course designers to keep in mind what the learners want to know after taking the course. Besides, Hutchinson and Waters' (1987) definition of "wants" and Berwick's definition of "felt needs" resemble each other as both of them are related with the learners' own perceptions about their needs.

\subsubsection{Learning Needs}

According to Hutchinson and Waters (1987), it is always inadequate to base a course design simply on the target objectives, just as it is not enough to think that a journey can be planned solely in terms of the starting point and the destination. The needs, potential, and constraints (learning situation) of the route must also be taken into account. Learning needs concerns about the route between the starting point (lacks) and the destination (necessities). For examples, learners may be greatly motivated in the subject or work, but may completely lose interests with the long, dull, and old teaching material. The learning process should be enjoyable, fulfilling, manageable, and generative. It is not concerned with knowing, but with the learning. The concept of "learning needs" put forward by Hutchinson \& Waters and their analysis of "learning needs" have been proved to be fairly useful in practice. As a result, in the process of leaning, learner's needs should always be taken into consideration. Course designers need to analyze the learner' learning needs according to their motivation, the conditions of the learning situation, and their existing knowledge and skills.

Besides, product-oriented and process-oriented needs are the counterparts of target needs and learning needs respectively put forward by Hutchinson \& Water(1987), in which the former emphasis on the requirement in learning in the target situation and is situation-specified and result-oriented, the latter attaches more importance to the whole process. 


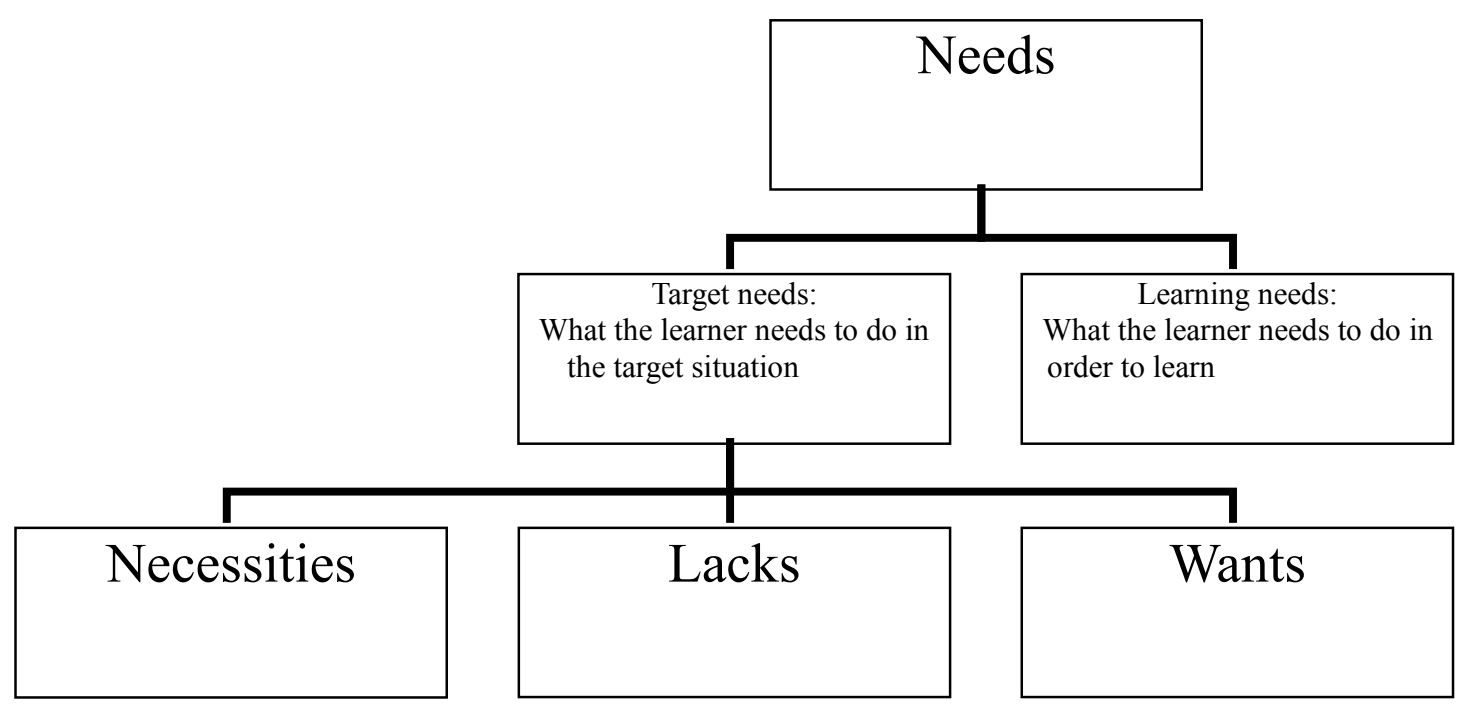

Figure 1. Hutchinson \& Waters'(1987) Classification of Needs analysis

\subsection{Needs Classified from the Perspective of Outsiders or Insiders}

There exists another classification of needs, which is viewed from the point of view of the outsiders or insiders. According to this criterion, objective needs and perceived needs are viewed from the outsiders and are based on facts or on what is already known; on the other hand, subjective and felt needs are derived from insiders and has something to do with the learning cognitive and affective factors. Briefly, objective and perceived needs are seen as derived by outsiders from facts, from what is known and can be verified, while subjective and felt needs are derived from insiders and correspond to cognitive and affective factors. Dudley-Evans \& St. John, 1998)

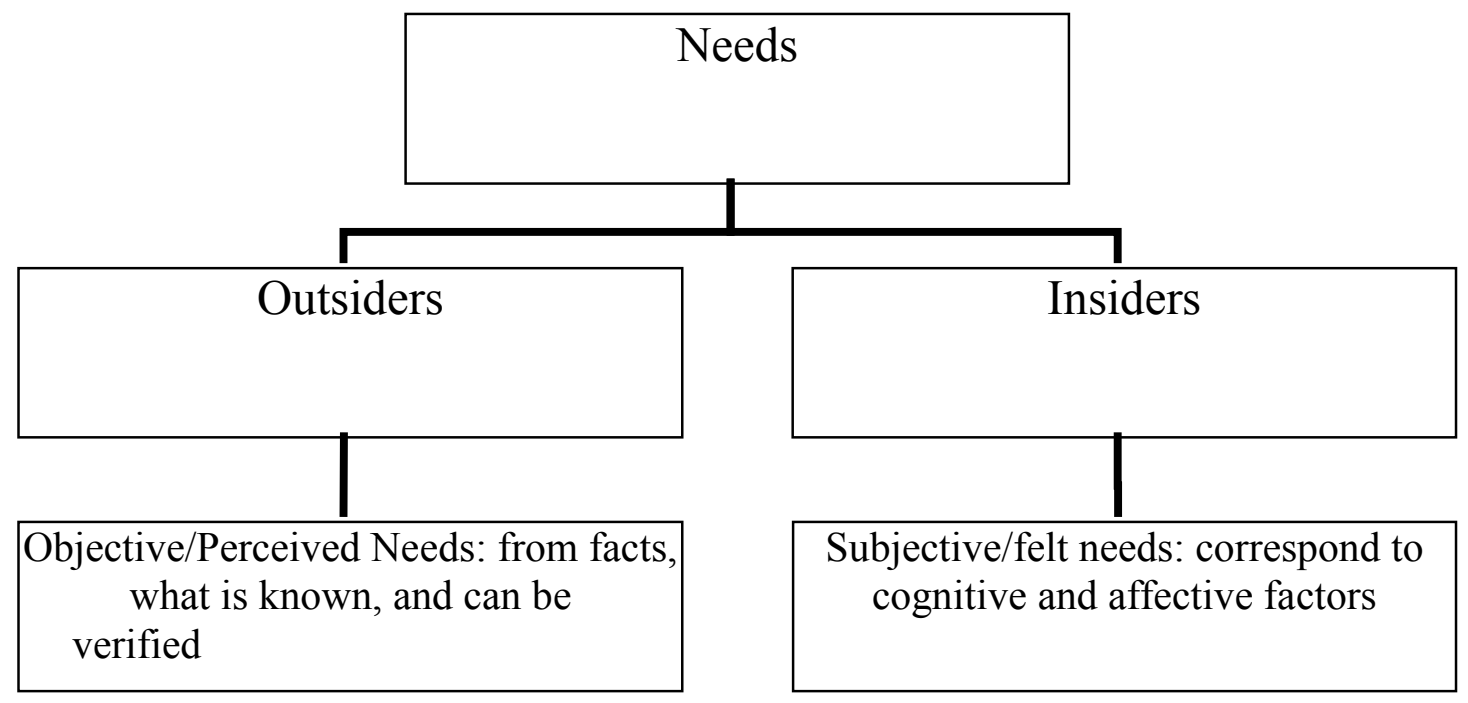

Figure 2. Insiders/outsiders Viewpoints on Needs

\subsection{Situational Needs and Communicative Needs}

One of the other classifications of needs types is situational and communicative needs. Situational needs focus on the general parameters of a language program and involve the goals, expectations, learning styles, and proficiency levels of learners. Situational needs include the teachers' expectations, teaching styles and techniques. Communicative needs refer to the learners' needs in the target situation. Communicative needs are concerned with the setting in which the learners will use the target language, the learners' role in relationships in the target situation, necessary language skills (reading, writing, speaking, listening), the learners' future interactions and language tasks, and the level of language proficiency that is required by the target situation (Richards, 1990). Richards' definition of communicative needs and Hutchinson and Waters'(1987) definition of target needs partially overlap as both of them refer to the learners' needs in the target situation. The main difference between communicative needs and target needs is that while communicative needs directly focus on the language necessities of the learners in their target situation, target needs make comparisons between the required language abilities of the target situation and the existing language proficiencies of the learners, and define the gaps between the present and target situation.

Besides the prevailing classifications about needs, Nunan (1999) prefers to draw a distinction between "content needs" and "process needs". Content needs include the selection and sequencing of such things as topics, grammar, function, notions, and vocabulary, while process needs refer to the selection and sequencing of learning tasks and experiences. A 
Chinese expert, Shu Dingfang (2004), has discussed two main needs, namely, society's needs and learners' needs. Society's needs refer to government's needs and social organization's needs, while learners' needs include objective information and subjective information. Objective information, in his opinion, refers to learners' present foreign language level, age, educational background, learning experience, while subjective information refers to learners' preferable length and intensity of the course, learning goals and teaching methods.

\section{Conclusion}

Needs analysis is compared to the diagnosis before the doctor's prescription in foreign language teaching (Long, 2005). To summarize, needs are described as perceived and felt, objective and subjective, situational or communicative, situation or language, target situation/goal-oriented and learning, process-oriented and product-oriented; in addition, there are necessities, wants and lacks. These terms have been introduced to describe the different factors and perspectives that have helped the concept of needs to grow. Each of these terms represents a different philosophy or educational value, and merits careful thought.

\section{References}

Berwick, R. (1989). Needs assessment in language programming: from theory to practice. In R. Johnson (Ed.), The Second Language Curriculum (pp.52). Cambridge: Cambridge University Press.

Brindley, G. P. (1984), Needs Analysis and Objective Setting in the Adult Migrant Education Program. Sydney, Australia: N.S.W. Adult Migrant Education Service.

Brindley, G. (1989). The role of needs analysis in adult ESL programme design. In R. Johnson(Ed.). The Second Language Curriculum (pp.35-70). Cambridge: Cambridge University Press.

Brown, J. D. (1995). The elements of language curriculum. Boston, MA: Heinle \& Heinle.

Brown, J. D. (2001). Using surveys in language programs. Cambridge: Cambridge University Press.

Dudley-Evans, T., \& St. John, M.J. (1998). Developments in ESP: a multi-disciplinary approach. Cambridge: Cambridge University Press

Graves, K. (2000). A framework of course development processes. In D.R. Hall \& A. Hewings(Eds.), Innovation in English language teaching (pp. 179-196). London: Routledge.

Hutchinson, T., \& Waters, A. (1987). English for Specific Purposes. Cambridge: Cambridge University Press.

Li, Juan. (2011). Curriculum Design for Business English Students Based on Needs Analysis Theory: A Case Study of Shandong Jiaotong University. Unpublished master's thesis, Shandong Normal University, Jinan.

Long, M. (2005). Second Language Needs Analysis. Cambridge: Cambridge University Press.

Shu, Dingfang (2004). FLT in China: Problems and Suggested Solutions. Shanghai:Shanghai Foreign Language Education Press.

Mountfourd, A. (1981). The Way and the Way. London: London: Longman Group.

Munby, J. (1978). Communicative Syllabus Design. Cambridge: Cambridge University Press.

Nunan, D. (1988). Syllabus design. Oxford:Oxford University Press.

Nunan, D. (1999). Second Language Teaching and Learning. Boston: Heinle \& Heinle Publishers.

Pratt, D. (1980). Curriculum design and development. New York: Harcourt Brace

Richterich R. \& Chancerel L.(1980). Identifying the needs of adults learning foreign language, Oxford: Pergamon Press for the Council of Europe.

Robinson, P. (1991). ESP Today: A Practitioner's Guide. Hemel Hempstead: Prentice Hall.

West, R. (1997). Needs Analysis: State of the Art. In R. Howard, G. Brown (Eds.), Teacher Education for LSP (pp.6879). Clevedon, UK: Multilingual Matters Ltd.

White, R. (1988), The ELT Curriculum. Blackwell, Oxford.

Widdowson, H.G.(1981). English for specific purposes: Criteria for course design. In Selinker et al. (Eds.), English for Academic and Technical Purposes: studies in honor of Louis Trimble (pp.1-11). Rowley: Newbury House. 